\title{
IS THERE ANY POTENTIAL IN SERVICE TRADE OF SOUTH ASIA?
}

\section{Sandeep Kaur*. Sangeeta Khorana**, Manpreet Kaur***}

Abstract: Like many developing economies, services have emerged as crucial economic activities in South Asia, yet this cannot increase the rapid growth in the intra-trade in the region. To find out the service trade potential in the region, this paper uses revealed comparative advantage indices to assess the comparative advantage and the indicative trade potential of different South Asian countries in various services sub-sectors. The study reveals that there stands complementarities in the trade of services as Pakistan and Sri Lanka have a competitive advantage in Transport Services, while India has a competitive advantage in Computer and Information Services and Other Business Services. In travel services, Maldives and Nepal possess competitiveness while Bangladesh in Government Services. The study reveals that competitive services have not explored the potential yet. India being the most robust economy of the region must provide a pivotal role in making negotiations and commitments under SAARC Agreement on Trade in Services (SATIS) particularly in competitive services.

Key Words: Trade, Services, SAARC, Regional Trade Agreements

JEL: F1, G2, F5

\author{
*Assistant Professor, Department of Economic Studies, Central University of Punjab, Bathinda \\ ** Professor, Bournemouth University, UK \\ *** Research Scholar, Department of Economic Studies, Central University of Punjab, Bathinda
}




\section{Introduction}

South Asian countries have attempted to achieve economic integration through the formation of the South Asia Association for Regional Co-operation (SAARC) in 1985; the original member countries were Bangladesh, Bhutan, India, Maldives, Nepal, Pakistan, and Sri Lanka. In a bid to accelerate the growth of trade among South Asian countries, the South Asian Preferential Trading Agreement (SAPTA) was concluded in 1995.The formation of SAPTA did little to develop trade among the countries in the region. Hence, the South Asian Free Trade Agreement (SAFTA) was signed in 2006. The main aim of the SAFTA was to reduce tariffs over ten years. As in the case of other initiatives, the agreement did little to foster trade among the countries in the region. This was followed by the signing of the SAARC Agreement on Trade in Services (SATIS) at the $16^{\text {th }}$ SAARC summit held in Thimpu in 2010. The agreement entered into force on November 29, 2012 in accordance with Article-V of General Agreement on Trade in Services (SAARC 2010 \&2017). This Agreement has taken nearly two and half years for the specific commitments' conclusion, which reveals a slow move towards economic integration in South Asia (Kelegama 2015). Various SAARC meetings, summits have raised the issue of acceleration of economic integration in goods and services in the region. More specifically, the Eighteenth SAARC Summit stressed the need for 'the elimination of all non-tariff and para-tariff barriers and smooth and efficient transit of transport to accelerate the process for South Asian Economic Union (SAEU) in a phased and planned manner'. Two SAARC-ADB special meetings focussed the issue of trade facilitation, reduction in sensitive lists, and the SAARC Agreement on Trade in Services (SATIS) among other issues. The $8^{\text {th }}$ meeting of SAARC finance ministers focused on a review of the progress in the implementation of their earlier decisions (SAARC 2017). 
There have been significant structural changes in South Asian economies partly resulting from globalization. This has resulted the rapid growth in the services sector of the region particularly in India where the contribution of services to overall growth has been significant and which has attracted substantial foreign direct investment (FDI) into the sector (IBEF 2017). Despite the structural changes in South Asian economies over the past decade, the region has remained inward-looking (Nyatanga 2017). In particular, trade among South Asian countries has remained much below potential, partly because of tariff and non-tariff barriers (Kaur and Nanda, 2010). According to the World Bank's Services Trade Restriction Index (2017), increasing trade within the region will require the elimination of tariff and non-tariff barriers, leveraging of private and interregional investment, investment in efficient connectivity and border crossings and liberalising services: logistics, shipping, air travel, etc. (World Bank 2017). The present paper attempts to find out the competitiveness and the potential for services trade and explore the possibility of improving and diversifying service trade in the South Asian region. The paper is divided into four sections including the present one. Section 2 explains the trends, composition, and competitiveness of services trade in South Asia. Section 3 reviews GATS negotiations which South Asian nations were party to and the last section summarises the findings of the paper with some important suggestions.

\section{Trends, Composition, And Competitiveness of Services Trade}

\subsection{Macro Economic Performance of South Asia}

SAARC is a small regional bloc that has grown relatively slowly compared to other existing regional economic blocs like the European Union (EU) and Association of Southeast Asian Nations (ASEAN),. Table 1 shows the macroeconomic performance of SAARC nations. The SAARC region constitutes 23.73 per cent of the world population, but it has only 15 per cent of 
the world's arable land. It contributes 3.82 per cent in world GDP. In world exports, it accounts for 3.68 per cent and in imports, it contributes US $\$ 4962970$ million (3.68 per cent) respectively. In net FDI inflow, it has received US $\$ 50844.45$ billion, (2.09 per cent) from the world.

Table 1: Macro Economic Indicators of SAARC Economies (2015-16)

\begin{tabular}{|l|c|l|l|l|c|l|l|}
\hline Indicators & $\begin{array}{l}\text { Population } \\
\text { (Millions) }\end{array}$ & $\begin{array}{l}\text { GDP } \\
\text { (Current } \\
\text { US\$ } \\
\text { Trillion) }\end{array}$ & $\begin{array}{l}\text { GDP Per } \\
\text { Capita } \\
\text { (Current } \\
\text { US\$ } \\
\text { Thousands) }\end{array}$ & $\begin{array}{l}\text { FDI net Inflow } \\
\text { (Millions) }\end{array}$ & $\begin{array}{l}\text { Exports in } \\
\text { (Millions) }\end{array}$ & $\begin{array}{l}\text { Imports } \\
\text { (Millions) }\end{array}$ & $\begin{array}{l}\text { Trade } \\
\text { balance } \\
\text { (billions) }\end{array}$ \\
\hline World & 7442.14 & 75.94 & 10.20 & 2436511 & 4962970 & 4870960 & 92010 \\
\hline $\begin{array}{l}\text { Share of } \\
\text { SAARC in } \\
\text { the world }\end{array}$ & 23.73 & & & & & & \\
\hline $\begin{array}{l}\text { SAARC } \\
\text { Total }\end{array}$ & 1766.38 & 2.82 & 16.1 & 2.09 & 3.68 & 3.29 & 0.39 \\
\hline Afghanistan & 34.656 & 0.019 & 0.562 & 93.58944 & 483.877 & 1298.05 & -814.173 \\
\hline Bangladesh & 162.952 & 0.221 & 2.774 & 11.88416 & 3532.507 & 7784.163 & -4251.66 \\
\hline Bhutan & 0.79777 & 0.002 & 1.359 & 2332.725 & 145.695 & 196.039 & -50.344 \\
\hline India & 1324.17 & 2.274 & 1.717 & 44458.57 & 161819 & 133531.6 & 28287.4 \\
\hline Maldives & 0.41749 & 0.004 & 9.872 & 456.6391 & 2891.359 & 1103.36 & 1787.999 \\
\hline Nepal & 28.9828 & 0.021 & 0.729 & 105.9964 & 1354.299 & 1250.784 & 103.515 \\
\hline Pakistan & 193.203 & 0.279 & 1.442 & 2488 & 5104 & 8871 & -3767 \\
\hline Sri Lanka & 21.203 & 0.082 & 3.857 & 897.0494 & 7138.115 & 6198.887 & 939.228 \\
\hline
\end{tabular}

Source: World Development Indicators, World Bank (2015-16)

Note: Values of various indicators for Afghanistan and Nepal is available for 2016.

\subsection{Composition of Services Trade in South Asia}

SAARC contributed $3.7 \%$ of the global trade in services in 2016 , much higher than the $1.4 \%$ in 2000 (Table 2). Various agreements like South Asian Free Trade Agreement (SAFTA) and SAARC Agreement on Trade in Services (SATIS) have provided a boost to trade in goods and services. SAARC's contribution to world trade is the highest in telecommunications, computer and information services - 15.1 per cent of world trade - but this is primarily due to India's contribution. In other services like government services, other business services, personal, cultural and recreational services, construction services and travel services, the contribution of SAARC is 5.6 per cent, 5.1 per cent, 2.9 per cent, 2.7 per cent, and 2.4 per cent respectively in 
2016. Almost all service exports from SAARC shows an increasing trend during the period 2000-2016.

Table 2: Share of Service Exports of SAARC to World (\%)

\begin{tabular}{|c|c|c|c|c|c|}
\hline Year & 2000 & 2005 & 2010 & 2016 & $\begin{array}{c}\text { Average } \\
(2000-2016)\end{array}$ \\
\hline Total Services & 1.4 & 2.3 & 3.4 & 3.7 & 2.73 \\
\hline Transport Services & 1.0 & 1.4 & 2.0 & 2.3 & 1.71 \\
\hline Travel Services & 0.9 & 1.2 & 1.9 & 2.4 & 1.55 \\
\hline Communication Services & 2.5 & 3.3 & 2.5 & - & 2.97 \\
\hline Construction Services & 1.8 & 0.8 & 1.7 & 2.7 & 1.43 \\
\hline Insurance Services & 1.1 & 2.1 & 2.0 & 1.9 & 1.88 \\
\hline Financial Services & 0.3 & 0.7 & 2.3 & 1.3 & 1.19 \\
\hline Computer and Information Services & 9.0 & 15.6 & 18.5 & 15.1 & 15.5 \\
\hline Royalties and Licence Fees Services & - & - & 0.1 & 0.2 & 0.08 \\
\hline Other Business Services & 1.6 & 3.2 & 3.8 & 5.1 & 3.34 \\
\hline Personal, Cultural and Recreational Services & 0.2 & 0.5 & 1.1 & 2.9 & 1.41 \\
\hline Government Services & 4.6 & 5.0 & 8.1 & 5.6 & 5.34 \\
\hline
\end{tabular}

Source: Authors calculation by using data source of UNCTAD and ITC, 2018.

Note: - indicates the unavailability of data. The collected data covers both the BPM Rev. 5 and BPM Rev. 6 Services Classification.

SAARC's share in world service imports was 3.3\% in 2016. Among all services, the maximum import share on an average was of 'other business services' (7.02 per cent). The other services in which SAARC has the major import share are transport services (5.05 per cent), insurance and pension services (3.56 per cent), personal, cultural, and recreational services (3.50 per cent), financial services (3.23 per cent), and telecommunications, computer and information services (2.59 per cent).

Table 3: Share of Services Imports of SAARC from World (\%)

\begin{tabular}{|l|c|c|c|c|c|}
\hline Service label & $\mathbf{2 0 0 0}$ & $\mathbf{2 0 0 5}$ & $\mathbf{2 0 1 0}$ & $\mathbf{2 0 1 6}$ & $\begin{array}{c}\text { Average } \\
\mathbf{( 2 0 0 0 - 2 0 1 6 )}\end{array}$ \\
\hline All Services & 1.7 & 2.9 & 3.5 & $\mathbf{3 . 3}$ & 2.73 \\
\hline Charges for the use of intellectual property rights & - & 0.7 & 1.1 & 0.2 & 1.35 \\
\hline Construction Services & - & 2.3 & 1.6 & 0.7 & 1.49 \\
\hline Financial Services & - & 1.3 & 4.7 & $\mathbf{3 . 5}$ & $\mathbf{3 . 2 3}$ \\
\hline Government Goods and Services & 1.0 & 1.2 & 1.4 & 1.6 & 1.27 \\
\hline Insurance and Pension services & - & 3.6 & 3.2 & 3.6 & $\mathbf{3 . 5 6}$ \\
\hline
\end{tabular}




\begin{tabular}{|l|c|c|c|c|c|}
\hline Maintenance and Repair Services & - & 1.0 & 0.4 & 0.3 & 0.68 \\
\hline Other Business Services & 1.4 & - & 3.6 & $\mathbf{2 1 . 5}$ & $\mathbf{7 . 0 2}$ \\
\hline Personal, Cultural, and Recreational Services & - & - & 10.6 & 1.2 & $\mathbf{3 . 5 0}$ \\
\hline Telecommunications, Computer, and Information Services & - & - & 2.3 & $\mathbf{3 . 5}$ & $\mathbf{2 . 5 9}$ \\
\hline Transport Services & 3.0 & 5.7 & 6.0 & $\mathbf{6 . 1}$ & $\mathbf{5 . 0 5}$ \\
\hline Travel Services & 8.1 & 1.2 & 1.5 & 1.7 & 1.85 \\
\hline
\end{tabular}

Source: Authors calculation by using data source of UNCTAD and ITC, 2018.

Note: - shows the unavailability of data, \& here also telecommunication, computer and information services are taken together because separate data on them is not available.

The average export and import shares of different services of SAARC nations are shown in Table 4 and Table 5. The table depicts that the region has many complementarities in the services trade among themselves. Among SAARC countries, Afghanistan's contribution was mainly in more in construction (26.2\%) and other business services (15.8\%). Bangladesh and Pakistan in government services, 55.9\% and 37.2\% respectively, Bhutan, Maldives, Nepal, and Sri Lanka in travel services, $61.9 \%, 92.0 \%, 40.5 \%$, and $29.4 \%$ respectively and India in computer and information services,32.3\% and other business services 32.6\%. Pakistan and Sri Lanka also contributed significantly to the export of transport services. An interesting development is that trade in services has diversified with trade taking place in financial services, computer and information services, communication services and insurance services, apart from that in traditional services like transport and travel.

Table 4: Average Export Share of Various Services of SAARC Nations (\%) (2000-16)

\begin{tabular}{|l|c|c|c|c|c|c|c|c|}
\hline Category & AFG & BGD & BTN & IND & MDV & NPL & PAK & LKA \\
\hline Total Services & 100 & 100 & 100 & 100 & 100 & 100 & 100 & 100 \\
\hline Transport Services & 5.88 & 9.15 & $\mathbf{2 7 . 3}$ & $\mathbf{1 1 . 3}$ & 4.97 & 6.71 & $\mathbf{3 0 . 7}$ & $\mathbf{4 1 . 0}$ \\
\hline Travel Services & 10.0 & 5.01 & $\mathbf{6 1 . 9}$ & $\mathbf{1 4 . 2}$ & $\mathbf{9 2 . 0}$ & $\mathbf{4 0 . 5}$ & 5.88 & $\mathbf{2 9 . 4}$ \\
\hline $\begin{array}{l}\text { Communications } \\
\text { Services }\end{array}$ & $\mathbf{1 1 . 6}$ & 7.12 & 1.15 & 2.55 & 2.32 & $\mathbf{1 2 . 7}$ & 7.35 & 3.33 \\
\hline Construction Services & $\mathbf{2 6 . 2}$ & 0.93 & 2.24 & 0.98 & - & - & 0.66 & 1.83 \\
\hline Insurance Services & 1.81 & 0.39 & 3.53 & 1.63 & 0.18 & 0.34 & 1.06 & 4.98 \\
\hline Financial Services & 9.20 & 1.86 & 0.29 & 3.14 & - & - & 1.29 & 4.92 \\
\hline $\begin{array}{l}\text { Computer And } \\
\text { Information Services }\end{array}$ & 1.45 & 1.78 & - & $\mathbf{3 2 . 3}$ & - & - & 3.47 & 9.04 \\
\hline Royalties And Licence & 0.02 & 0.02 & 0.09 & 0.23 & 1.14 & - & 0.39 & - \\
\hline
\end{tabular}




\begin{tabular}{|l|c|c|c|c|c|c|c|c|}
\hline Fees Services & & & & & & & & \\
\hline Other Business Services & $\mathbf{1 5 . 8}$ & $\mathbf{1 7 . 5}$ & 1.52 & $\mathbf{3 2 . 6}$ & - & $\mathbf{1 7 . 7}$ & $\mathbf{1 1 . 5}$ & 9.32 \\
\hline $\begin{array}{l}\text { Personal, Cultural And } \\
\text { Recreational Services }\end{array}$ & 2.09 & 0.15 & - & 0.50 & - & - & 0.08 & - \\
\hline $\begin{array}{l}\text { Government Services } \\
\text { n.i.e*. }\end{array}$ & $\mathbf{1 1 . 5}$ & $\mathbf{5 5 . 9}$ & 5.58 & 0.95 & 0.70 & $\mathbf{2 3 . 3}$ & $\mathbf{3 7 . 2}$ & 1.11 \\
\hline
\end{tabular}

Source: Authors calculation by using data source of UNCTAD and ITC, 2018.

Note: --- indicates unavailability of data. * Not Included Elsewhere

In the case of services imports, Afghanistan accounts for a major share in transport services (66.6

$\%)$ followed by insurance services (12.2\%), Bangladesh in transport service (73.2 \%),

government services (6.27\%) and other business services (5.55\%), Bhutan in travel (35.0\%) and transport $(21.8 \%)$ and India imports in transport services $(42.7 \%)$ followed by other business services $(24.2 \%)$.

Table 5: Average Import Share of Various Service of SAARC Nations (\%) (2000-16)

\begin{tabular}{|l|c|c|c|c|c|c|c|c|}
\hline Category & AFG & BGD & BTN & IND & MDV & NPL & PAK & LKA \\
\hline Total Services & 100 & 100 & 100 & 100 & 100 & 100 & 100 & 100 \\
\hline Transport Services & $\mathbf{6 6 . 6}$ & $\mathbf{7 3 . 2}$ & 21.8 & $\mathbf{4 2 . 7}$ & $\mathbf{4 1 . 7}$ & $\mathbf{3 7 . 1}$ & $\mathbf{4 7 . 6}$ & $\mathbf{5 7 . 9}$ \\
\hline Travel Services & 7.71 & 7.53 & $\mathbf{3 5 . 0}$ & $\mathbf{1 2 . 0}$ & $\mathbf{3 6 . 7}$ & $\mathbf{4 0 . 3}$ & $\mathbf{1 6 . 0}$ & $\mathbf{1 7 . 7}$ \\
\hline Communications Services & 2.62 & 0.55 & 1.50 & 1.37 & 8.45 & 2.54 & 1.66 & 1.58 \\
\hline Construction Services & 2.22 & 0.59 & $\mathbf{2 4 . 4}$ & 1.47 & 2.86 & - & 0.60 & 0.32 \\
\hline Insurance Services & $\mathbf{1 2 . 2}$ & 3.67 & 2.26 & 4.59 & 4.31 & 4.43 & 2.25 & 6.53 \\
\hline Financial Services & 1.83 & 2.16 & 0.21 & 4.59 & 0.03 & - & 1.87 & $\mathbf{1 0 . 1 7}$ \\
\hline Computer And Information & 0.56 & 0.13 & 0.40 & 2.98 & 1.16 & - & 1.50 & 6.75 \\
\hline Royalties And Licence Fees & 0.01 & 0.29 & 0.16 & 2.23 & 0.52 & - & 1.44 & - \\
\hline Other Business Services & 3.67 & 5.55 & 9.60 & $\mathbf{2 4 . 2}$ & $\mathbf{1 0 . 8}$ & $\mathbf{1 4 . 3}$ & $\mathbf{2 0 . 7}$ & $\mathbf{1 2 . 3}$ \\
\hline $\begin{array}{l}\text { Personal, Cultural And } \\
\text { Recreational Services }\end{array}$ & 0.27 & 0.03 & - & 0.48 & 2.13 & - & 0.09 & - \\
\hline Government Services n.i.e.* & & & & & & & & \\
\hline
\end{tabular}

Source: Authors calculation by using data source of UNCTAD and ITC (2018)

Note: --- indicates unavailability of data.

*Not Included Elsewhere

India has a comparative advantage not only from SAARC nations but also in the world, which stands $2^{\text {nd }}$ only to European Union (OECD 2017).

\subsection{Competitiveness of South Asian Countries in Services Trade}


The Revealed Comparative Advantage ${ }^{1}$ analysis of SAARC exports shows that this region is competitive in different categories of services (Table 6).

The main services in which the SAARC region has a comparative advantage are telecommunications, computer and information services, other business services and government services.

Table 6: Revealed Comparative Advantage (RCA) of SAARC in Services Trade

\begin{tabular}{|l|c|c|c|c|c|c|}
\hline Services/Year & $\mathbf{2 0 0 0}$ & $\mathbf{2 0 0 5}$ & $\mathbf{2 0 1 0}$ & $\mathbf{2 0 1 3}$ & $\mathbf{2 0 1 6}$ & $\begin{array}{c}\text { Average } \\
(\mathbf{2 0 0 0 - 2 0 1 6})\end{array}$ \\
\hline Transport Services & 0.72 & 0.58 & 0.59 & 0.63 & 0.61 & 0.63 \\
\hline Travel Services & 0.67 & 0.53 & 0.54 & 0.54 & 1.67 & 0.74 \\
\hline Communications Services & 1.87 & 1.42 & 0.74 & 0.86 & 0.20 & 2.08 \\
\hline Construction Services & 1.29 & 0.33 & 0.49 & 0.57 & 0.75 & 0.53 \\
\hline Insurance Services & 0.82 & 0.92 & 0.58 & 0.66 & 0.53 & 0.73 \\
\hline Financial Services & 0.25 & 0.30 & 0.67 & 0.53 & 0.35 & 0.41 \\
\hline Computer and Information Services & $\mathbf{6 . 5 9}$ & $\mathbf{6 . 7 3}$ & $\mathbf{5 . 3 7}$ & $\mathbf{4 . 8 5}$ & $\mathbf{4 . 1 5}$ & $\mathbf{5 . 9 7}$ \\
\hline Royalties and Licence fees Services & 0.10 & 0.04 & 0.02 & 0.04 & 0.60 & 0.14 \\
\hline Other Business Services & $\mathbf{1 . 1 9}$ & $\mathbf{1 . 3 6}$ & $\mathbf{1 . 0 9}$ & $\mathbf{1 . 1 9}$ & $\mathbf{1 3 . 8}$ & $\mathbf{2 . 6 4}$ \\
\hline $\begin{array}{l}\text { Personal, Cultural and Recreational } \\
\text { Services }\end{array}$ & 0.10 & 0.22 & 0.32 & 0.81 & & \\
\hline Government Services & & & & & 0.80 & 0.45 \\
\hline
\end{tabular}

Source: Authors' calculations based on the data from UNCTAD (2000-2016).

The revealed comparative advantage has decreased in transport, travel, construction and computer, and information services between 2000 and 2016. However, it has increased in insurance services, other business services, and government services. South Asia's export interests lie in the area of labour-intensive and manpower-based services while its import interests are in the areas of the capital and technology-intensive services, which enhances productivity. Construction, education, tourism and health services are of special significance for both exports as well as imports. If one looks at the RCA for different services, it is apparent that the highest RCA is in the case of computer and information services followed by government 
services, other business services while the other services like transport and travel have low RCA value, which is less than one.

The average RCA analysis of South Asian countries for 2000-16 is presented in Table 7. The table shows South Asian countries have competitive advantage in different categories of services.

Table 7: RCA of Various Services in South Asia (2000-16)

\begin{tabular}{|l|c|c|c|c|c|c|c|c|}
\hline Name of Services & AFG & BNG & BHU & IND & MAL & NEP & PAK & SLK \\
\hline Transport & 0.41 & 0.43 & 1.19 & 0.55 & 0.26 & 0.25 & 1.35 & 1.92 \\
\hline Travel & 0.12 & 0.17 & 2.15 & 0.51 & 3.58 & 1.55 & 0.23 & 1.36 \\
\hline Communications & 2.49 & 3.66 & 0.38 & 0.83 & 0.82 & 7.27 & 2.89 & 1.27 \\
\hline Construction & 13.8 & 0.51 & 0.00 & 0.38 & 0.02 & 0.00 & 0.27 & 0.61 \\
\hline Insurance & 0.64 & 0.12 & 1.04 & 0.65 & 0.02 & 0.17 & 0.47 & 1.46 \\
\hline Financial Services & 1.35 & 0.23 & 0.03 & 0.47 & 0.00 & 0.00 & 0.19 & 0.33 \\
\hline Computer and Information & 0.11 & 0.43 & 0.00 & 6.03 & 0.00 & 0.00 & 0.84 & 1.86 \\
\hline Royalties and Licence Fees & 0.00 & 0.00 & 0.01 & 0.04 & 0.06 & 0.00 & 0.05 & 0.00 \\
\hline Other Business Services & 1.43 & 0.64 & 0.01 & 1.29 & 0.00 & 0.72 & 0.53 & 0.23 \\
\hline $\begin{array}{c}\text { Personal, Cultural and } \\
\text { Recreational Services }\end{array}$ & 0.64 & 0.18 & 0.00 & 0.63 & 0.00 & 0.00 & 0.05 & 0.12 \\
\hline Government Services n.i.e* & $\mathbf{2 . 3 8}$ & $\mathbf{2 5 . 6}$ & 2.00 & 0.27 & 0.21 & $\mathbf{1 2 . 1}$ & $\mathbf{2 2 . 0}$ & 0.46 \\
\hline
\end{tabular}

Source: Author's calculation based on the data from UNCTAD (2018).

*Not Included Elsewhere

At an average Pakistan and Bangladesh have competitive advantage in government services while India has competitive advantage in computer and information services, and other business services. Afghanistan has competitive advantage in construction services while Bhutan and Maldives have competitive advantage in travel service trade. Nepal has competitiveness in communication service trade. In transport service trade, Pakistan and Srilanka has competitive advantage in This apparently indicates that there exist complementarities in service trade among these countries .

\subsubsection{Trade Potential among SAARC Countries}


Table 8 provides an indication of the intra- SAARC services' Trade potential famong the SAARC countries. India's export potential with SAARC has exhausted for all services except government services . Afghansistan, Maldives, Nepal, Pakistan and Sri Lanka' trade potential in Computer and Information Services and Other Business Services has not been explored yet. On the other hand, Bangladesh and Bhutan' trade potential in financial services is still underutilised. In remaining services transporatition, travel, construction, insurance and personal,cultural and recreational services, the potential in Afganistan, Bangladesh, Bhuatn, Maldives, Nepal and Pakistan, Sri Lanka is also underutilised. Only government services trade potential has explored in two countries Bangladesh and Pakistan. India's trade potential has explored in most of the services. The positive relation between competitiveness and unexploited trade potential shown in Figure 1 indicates that competitive services have not explored the potential yet. 
Table 8: Potential for Intra-SAARC Trade in Services (2016)

US \$ million

\begin{tabular}{|c|c|c|c|c|c|c|c|c|}
\hline Category & AFG & BAN & BHU & IND & MAL & NEP & PAK & SRI \\
\hline Total Services & 1577562 & 1537918 & 1603308 & -1500516 & 1560020 & 1580455 & 1465393 & 1508580 \\
\hline Transport & 212961.5 & 209320.6 & 214715.6 & -129091 & 212883 & 213986.8 & 176865.3 & 177551 \\
\hline Travel & 191844.7 & 189800.4 & 191409.4 & -211169 & 150975.9 & 182734.3 & $\overline{184515.6}$ & 159104.5 \\
\hline Communications & 38350.26 & 34414.54 & 39873.92 & -17484.7 & 39067.16 & 35846.27 & 30937.12 & 37156.82 \\
\hline Construction & 9614.62 & 17708.02 & 18504.46 & -8773.5 & 18478.57 & 18504.46 & 17625 & 17139.59 \\
\hline Insurance & 26208.07 & 26445.08 & 26576.67 & -21212.4 & 26613.36 & 26530.19 & 25065.17 & 23278.48 \\
\hline Financial Services & 56563.61 & 58235.24 & 59433.78 & -52342.4 & 59439.45 & 59439.45 & 57455.85 & 56981.14 \\
\hline Computer and Information & 516448.6 & 515034.3 & 516622.5 & -499312 & 516622.5 & 516622.5 & 510257.9 & 506821.2 \\
\hline Royalties and Licence fees & 4437.89 & 4429.51 & 4439.94 & -3224.9 & 4273.44 & 4441.12 & 3969.72 & 4441.12 \\
\hline Other Business Services & 470854.9 & 470141.5 & 480455.4 & -473387 & 480462.6 & 476165.4 & 462555.5 & $\overline{475239.3}$ \\
\hline $\begin{array}{l}\text { Personal, Cultural and } \\
\text { Recreational Services }\end{array}$ & 8620.82 & 8669.96 & 8779.83 & -8653.51 & 8779.83 & 8779.83 & 8718.23 & 8673.83 \\
\hline $\begin{array}{l}\text { Government } \\
\text { services n.i.e. (Not Included } \\
\text { Elsewhere) }\end{array}$ & 17380.48 & -12578.6 & 18498.98 & 3312.79 & 18410.72 & 13092.94 & -36748.8 & 17774.6 \\
\hline
\end{tabular}

Source: UNCTAD and ITC database, 2018

Note*mean Not Included Elsewhere 


\section{Fig I:Relation between RCA and Underdeveloped Trade Potential}

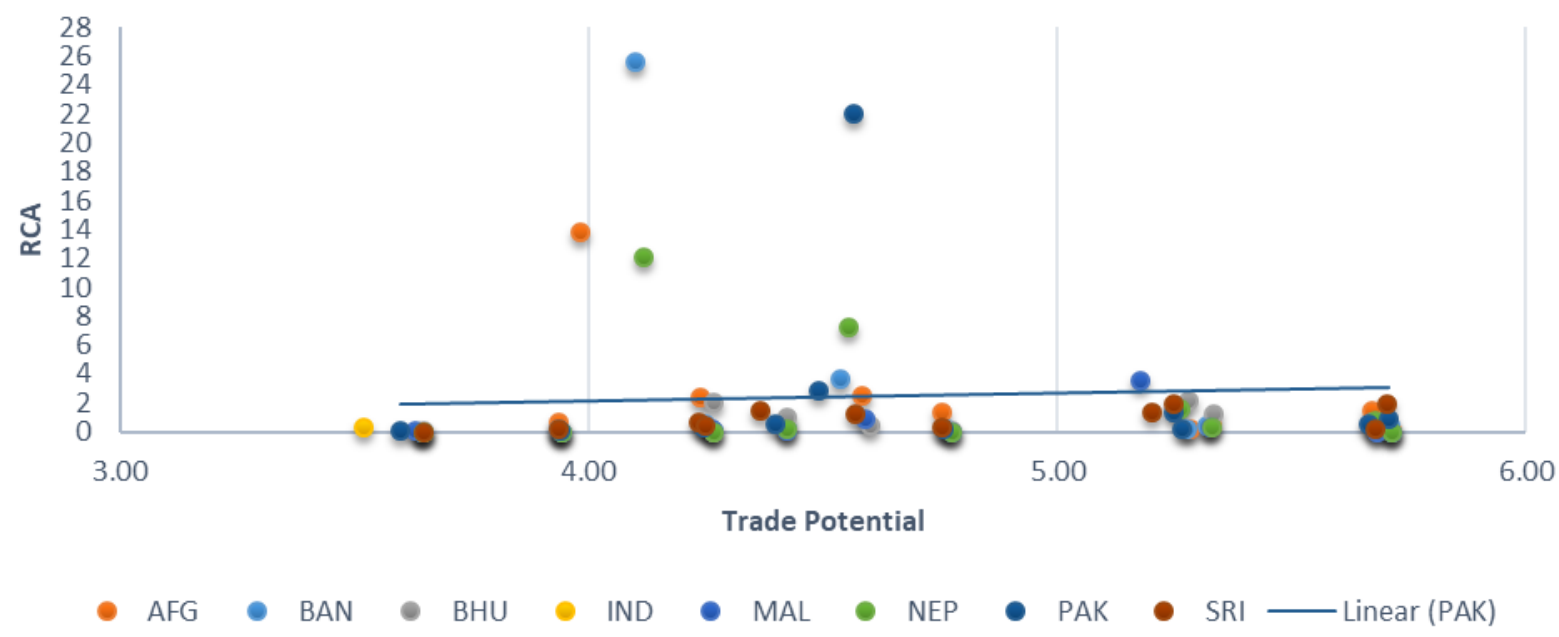

\section{South Asia and Gats Negotiations}

Countries like Bangladesh, India, Pakistan, and Sri Lanka are signatories to the General Agreement on Trade in Services (GATS) established in January 1995. The Hong Kong Ministerial Declaration of 2005 provided special treatment for trade in services (WTO, 2005) by least developed countries (LDCs).Among the four LDCs of South Asia Afghanistan, Bangladesh, Bhutan and Nepal, Bangladesh being a founder member of the WTO, benefited from the unique and differential treatment allowed to least developing countries during the Uruguay Round. With its accession to WTO in 2004, Nepal undertakes more commitments as compared to Bangladesh. However, Afghanistan and Bhutan are currently at various stages of their acceptance of negotiations.

The summary of negotiations from $10^{\text {th }}$ SAARC Summit in July 1998 to the $16^{\text {th }}$ summit in April 2010 focused on tourism, informal trade, completion of services in a time bound manner and to realise the full potential to integrate trade in services through SAFTA and liberalisation of regional trade in services (Razzaque and Basnett 2014). Initially, some South Asian countries 
expressed their dissatisfaction with existing commitments in Mode 4, which do not address the categories and skills of interest to developing countries and continue to apply discretionary and non-transparent barriers to the movement of services. However, these nations came under the considerable pressure from leading developed countries, and they are in the process of liberalizing trade under Mode 4. They had also received requests to liberalize key sectors such as telecommunication, banking, insurance, legal, accountancy, education, environment and retail distribution services (Chanda, 2011 \&2012). But with the passage of time, all SAARC countries (except Maldives) have committed to liberalising services like telecom services, tourism, and travel services with initial and revised offers under GATS. But the commitment of these nations remains narrow except Nepal and Pakistan.

Bangladesh has undertaken GATS commitments in government services, communication and construction services. After the Doha Round, India liberalised commitments in knowledge-based services such as computer related services in Mode 1 and Mode 4. India also wants commitments from its trading partners for temporary movement of high-skilled professionals in four categories - namely business visitors (BV), intra-corporate transferees (ICT), independent professionals (IP) and contractual service suppliers (CSS) (Mukherjee \& Goyal, 2013). Seeking support from many countries in broad-based commitments in these modes, India has made commitments in different services like communication services, computer and information services, other business services, financial services and tourism and travel related services. Maldives made commitments only in two services - professional services, and computer and related services. However, the commitments made by Maldives in these two services are fully liberalised - that is, no restrictions are placed on any mode of supply, in terms of either market access or national treatment. Nepal is the only country in the South Asian region that made higher degrees of 
commitment than other nations in terms of market access and national treatment. The overall level of commitment by Nepal is ten times higher than that of Bangladesh (Pandey, 2014). There are almost eleven sectors and subsectors in which Nepal has made commitments; these include transport services, tourism/travel services, business services, communication services, construction/engineering services, distribution services, financial services, health/social services, recreational/ cultural services, educational services, environmental services, and other services.

Pakistan has made commitments in business services, government services, communication services, construction services, financial services, engineering services, tourism and travel related services and health services. However, while making the commitments, Pakistan also made certain horizontal commitments, which restrict certain modes of supply under market access and national treatment. Pakistan has negotiated extensively and formulated a comprehensive schedule of commitments (Raihan 2013). Sri Lanka has made commitments only in some selected sectors like communication services, banking services, financial service and tourism and travel related services.

Afghanistan, Maldives, and Nepal have made commitments without restrictions under Mode1 and Mode 2 for transportation, travel, communications, financial, computer and information, other business services and personal, cultural and recreational services. But these countries remain unbound in some services under mode 3 and 4 , indicating that no commitment has been made. Other countries - Bangladesh, India, Pakistan, and Sri Lanka remain unbound in Mode 1 and 2 for transportation, travel, communication, construction, computer and information, other business services and personal, cultural and recreational services. Sri Lanka has made additional commitments o(related to the use of standards, qualifications or licenses) also. While the Maldives has put no restrictions on computer and information and other business services,(Table 
9). India and Bangladesh have made commitments under Mode 3 in market treatment, only through incorporation with a foreign equity ceiling of 51 per cent in travel services. For India, this commitment is with few specific services, namely travel, computer and information services, and other business services where investment approval would be required by the Foreign Investment Promotion Board. Mode 4 remains unbound, except as indicated in the horizontal section, Otherwise, it is very restricted in these services. . Similarly, Nepal made commitments in 'Computer and Information Services' under mode 3 and had maximum foreign equity capital of 80 per cent only through incorporation (Appendix I). These countries were substantially opening their economy for services trade (Mattoo, 2000) 
Table 9: Trade in Services Negotiations offered by South Asian Countries

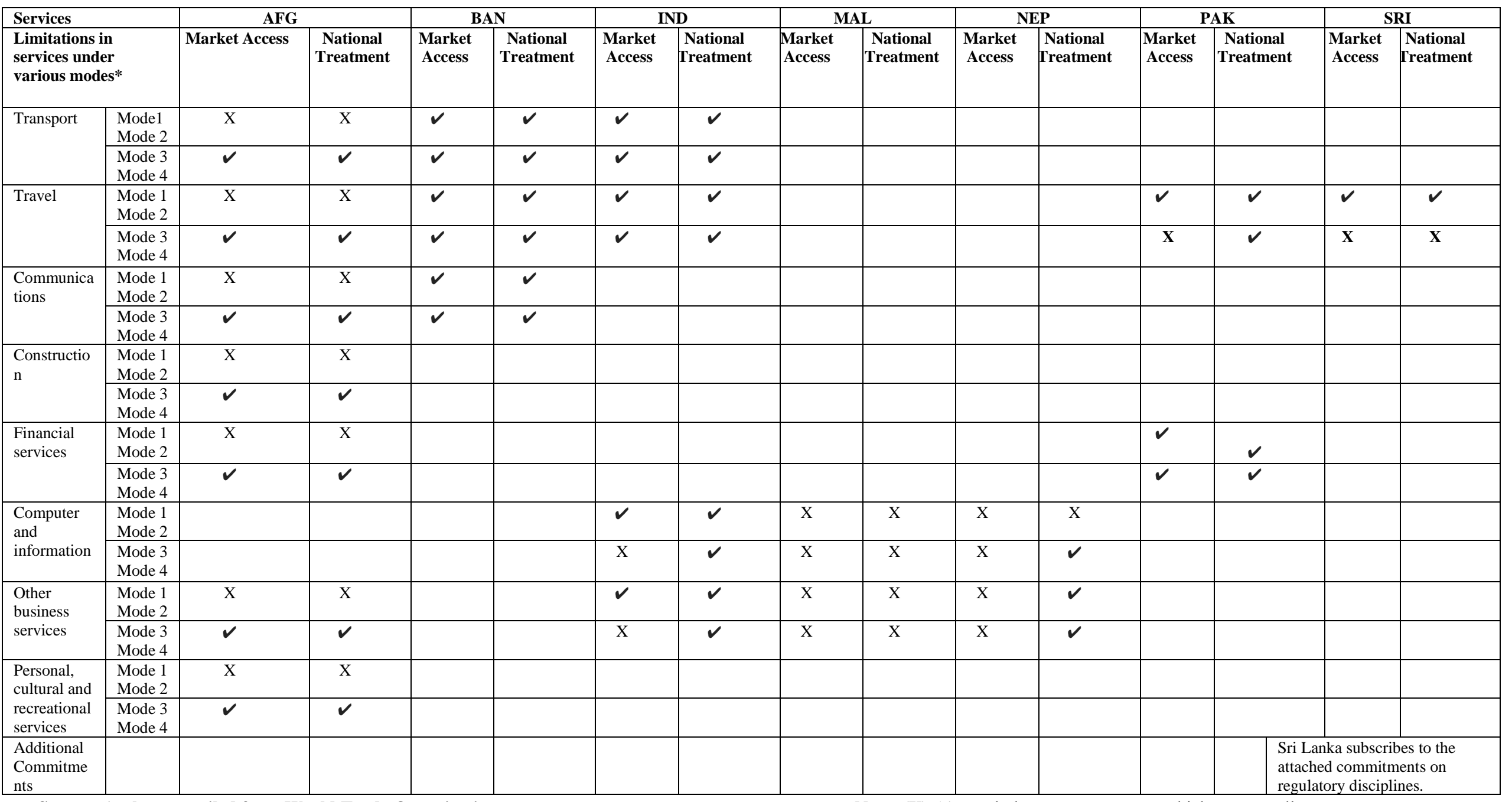

Source: Author compiled from World Trade Organization, http://i-tip.wto.org/services/SearchResultGats.aspx Note: (X) this symbol represents "none", which means Full

Commitment. $(\boldsymbol{V})$ represents unbound means "No Commitment". *Blank Box Shows Free Trade (partial commitment). 


\section{Barriers to Service Trade in South Asia}

The barriers to service trade index given by World Bank 2019 shows that South Asian countries impose restrictions on trade in various services. In telecommunication services and transport services, India and Bangladesh are comparatively more restrictive while Pakistan has the lowest restriction in this service. In retail services, it is India that imposes the most stringent restrictions and its service trade restrictiveness index $(\mathrm{STRI})^{2}$ value is (75), while Bangladesh, Nepal, and Sri Lanka are relatively less restrictive with an STRI value is 25. Only Pakistan does not impose any restriction on this service. In professional services and retail services, Indian and Nepal impose the heavy restrictions (STRI value is 87.5 and 76 respectively). Restrictions are more moderate in Pakistan and Sri Lanka (their STRI values are 48 and 57 respectively) while Bangladesh imposed the least restrictions (STRI value is 35).). India's STRI is the highest on rail freight transport (1) followed by legal (0.91), accounting (0.88), architecture (0.63), air transport (0.60), insurance(0.56). In the $11^{\text {th }}$ WTO ministerial conference, many countries including India highlighted issues related to domestic regulations and complexities put by some rich countries. It mainly stressed hurdles faced by natural persons supplying services in foreign jurisdictions (Arun, 2017). 


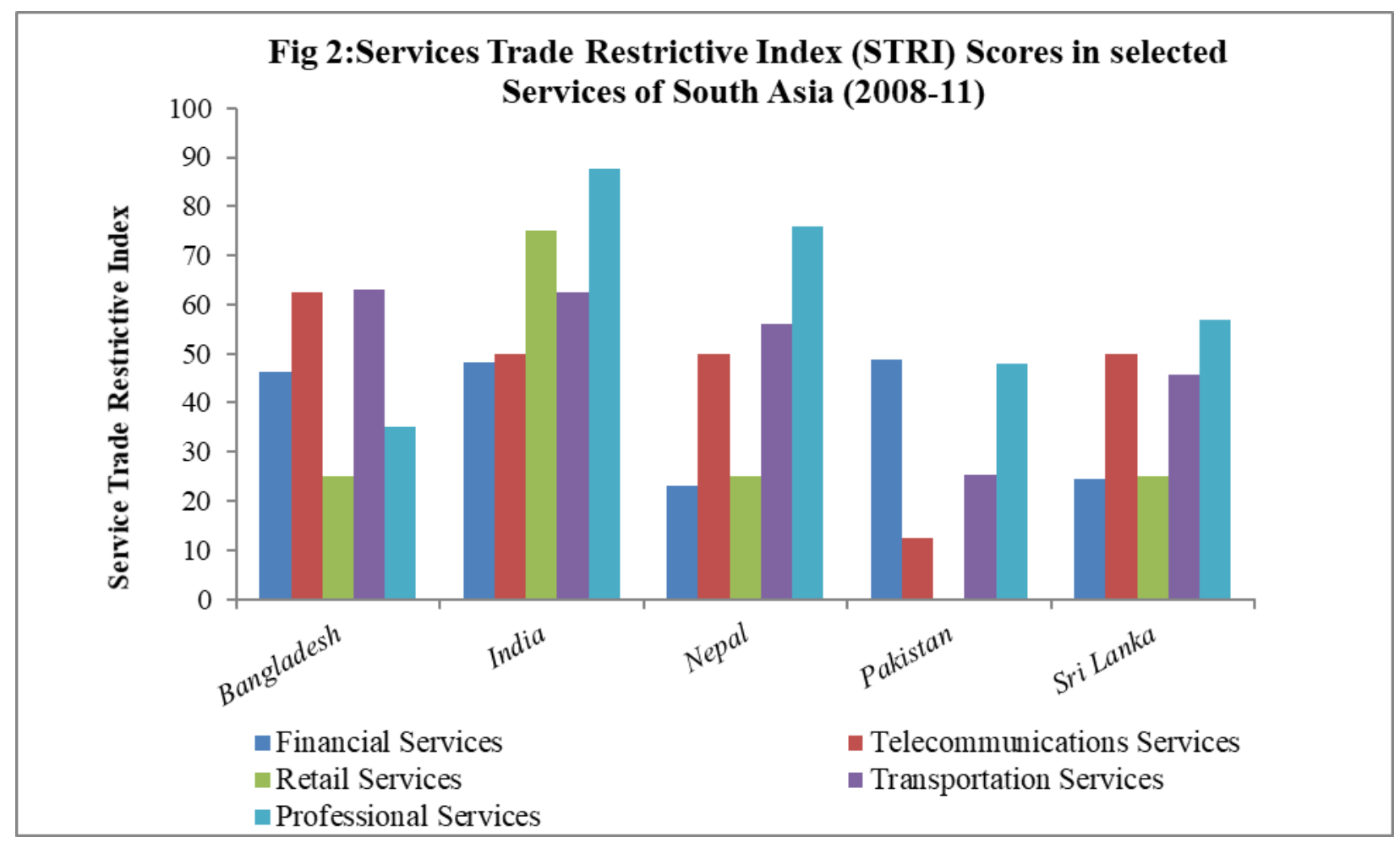

Source: World Bank, 2018

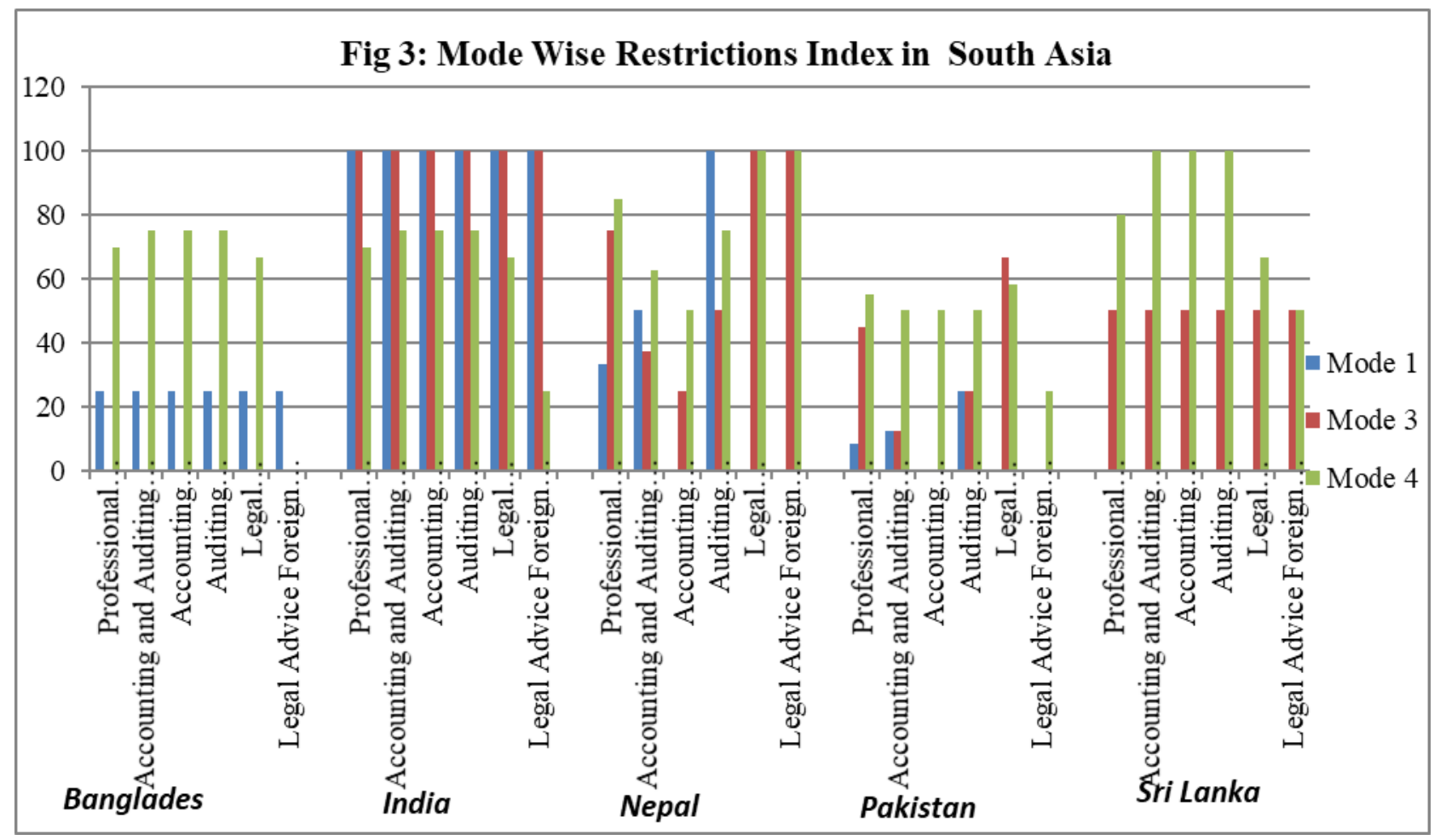

Source: World Bank, 2018 
Among regions, some of the fastest growing economies in Asia and Gulf were found to be highly restrictive with respect to services trade, especially in the case of professional and transport services, while services trade in the retail, telecommunication and even finance sectors are seen to be more open. These restrictions have not only constrained the rapid growth of services trade, they have also acted as disincentives to investment inflows into the sector. It was found that such restrictions could reduce foreign investment in the services sector by $\$ 2.2$ billion over a sevenyear period compared to open policy regimes (Borchert et al. 2013).

\section{Conclusions and Suggestions}

Service trade has a great potential in South Asian nations. However, trade in these services face substantial barriers especially strict visa, nationality, licensing requirement, fees, and charges, poor air and road connectivity. Thus, efforts should be made to remove the restrictions on the movement of people by improving air and road transport facilities and by providing easy access to passport and visa facilities. Given that poor connectivity is one of the major factor impeding growth in trade, an improvement in infrastructure would help to greatly boost trade.

Most SAARC nations have higher imports of transport services while Pakistan and Sri Lanka have greater RCA in this service. Hence, Pakistan and Sri Lanka should make efforts to provide higher priority to the transport sector under the ongoing SATIS negotiations

According to Prabir De and Iyengar (2014) South Asia needs to generate about 12 million jobs to sustain growth for every year. For that purpose, a substantial amount of jobs needs to be created in the manufacturing and associated logistics and services. Compared to East Asia and South East Asia, the manufacturing and related services sector have underperformed in South Asia due to constraints, which if removed can unlock the unexploited its economic potential. Building economic corridors and improving infrastructure may help boost trade and create more jobs. Bangladesh may emerge as a transport hub for the sub-region including Bhutan, Nepal, and India if Bangladesh opens its transport system for regional connectivity (De and Iyengar 2014).

Both the US and the EU are declining in economic power and changing role of Asia and its economic integration may be the driver of economic growth at the global level in the $21^{\text {st }}$ century (Lagarde 2016 and Shinohara 2012). Growing protectionism witnessed from USA-China trade war and the Brexit referendum open doors for emerging economies for trade liberalisation and economic integration. Besides, the fear that US protectionism may spread offers a gateway to 
developing countries to make a web of their own trade integration. These major changes come with many opportunities for developing SAARC economies as the Asia Pacific region accounts for more than 50\% of global trade (Macleod 2017 and Repeckaite 2017). Moreover, US has service export potential with India (Kaur 2011), but given the US move towards greater protectionism especially in IT services, India needs to look at other markets including South Asia.

South Asia seems to be the one of the fast-growing regions, and China and India are among the fastest growing economies (IMF 2016). India being most influential economy of this regional bloc, and it must play a decisive role in finalizing commitments under SATIS especially for regulations, standards, mobility of labour in competitive services.

\section{End Notes:}

1. Export competitiveness of individual product category is calculated by revealed comparative advantage index given by Balassa (1965). $R C A_{i j}=X i j / X w j / X i / X w$ where $R C A i j=$ Revealed comparative advantage of the ith country's jth service, $X_{i j}=$ Exports of the jth service by the ith country, $X_{i}=$ Total service exports of the ith country, Xwj = World exports of the jth service $X w=$ Total world exports of services.

2. ITP is defined as; $\boldsymbol{I T P}_{\boldsymbol{i j s}}=\min \left(\boldsymbol{X}_{i j s}, \boldsymbol{X}_{j}\right)-\boldsymbol{X}_{i j s}$ where, $\boldsymbol{I T P}_{i j s}=$ Indicative Trade Potential for country $i$ 's exports to country $j, X_{i s}=$ Country $i$ 's exports to world,$X_{j s}=S A A R C$ i's imports from WORLD $\boldsymbol{X}_{i j s}=$ Country $i$ 's exports to $S A A R C j$. ITP provides a rough estimate of how much countries 'theoretically' trade between them by isolating total demand and total export capacity (Yusuf, 2006). It helps to identify the major services for which there is the highest complementarity between the exports of a country and imports of the target country. A positive 'Indicative trade potential' suggests that a trade opportunity exists (Krakoff, 2003).

3. Services are traded through the four "Modes of Supply" in the GATS. As defined in WTO, Mode 1 known as "cross-border supply" refers to services provided from the territory of one Member country into the territory of any other Member country. Mode 2, "Consumption Abroad" refers to the territory of one Member to the service consumer of any other Member. Mode 3 refers to a service supplier of one Member, through "commercial presence" in the territory of any other Member. This mode covers any type of business or professional establishment including an affiliate, subsidiary, representative office or branch. Mode 4, 
which is covered by a service supplier of one Member, through "presence of natural persons" of a Member in the territory of any other Member (WTO, 2017).

4. The value of Services Trade Restrictiveness Index (STRI) lies between between zero (an open market) to one (closed to foreign services providers) (OECD, 2017).

\section{References}

Aftab, S.2014. South Asian regional cooperation: The India-Pakistan imperative. Faculty of Society and Design Publications. Bond University. http://epublications.bond.edu.au/fsd_papers/116 (accessed 10 May 2016).

Arun 2017. WTO: India battles Services Barriers. The Hindu. http://www.thehindu.com/business/Industry/wto-india-battles-servicesbarriers/article21381697.ece (accessed 2 Jan 2018).

Balassa, B.1965. Trade Liberalization and "Revealed" Comparative Advantage. The Manchester School 33(2), pp 99-123.

Benz, S., Khanna, A. and Nordas, H. 2017, "Services and Performance of the Indian Economy: Analysis and Policy Options," OECD Trade Policy Papers, No. 196, OECD Publishing, Paris.https://www.oecdilibrary.org/docserver/9259fd54en.pdf?expires=1536745244\&id=i $\mathrm{d} \&$ accname $=$ guest $\&$ checksum $=3$ DB6E70F05ED73B86E2C99C77DD07F10 $($ accessed 2 January 2018).

Borchert, I., Gootiiz, B., \& Mattoo, A.2012. Guide to the services trade restrictions database. Working Paper No. 6108. pp 1-30.

Borchert, I., Gootiiz, B., \& Mattoo, A. 2013. Policy Barriers to International Trade in Services: Evidence from a New Database. The World Bank Economic Review. 28(1).pp162-188.

Chanda, R. 2011. Integrating Services in South Asia: Trade, Investment, and Mobility. Oxford University Press.

Chanda, R. 2012. "Impact of Services Trade Liberalization on Employment and People. Asian Development Bank Institute,Japan. Working Paper No.339. pp 3- 17.

De, P., \& Iyengar, K. 2014. Developing Economic Corridors in South Asia. Asian Development Bank https://www.adb.org/publications/developing-economic-corridors-south-asia (accessed 20 May 2018).

Dhaka Declaration 2005. Thirteenth SAARC Summit, 13 November 2005.http://saarcsec.org/uploads/digital_library_document/13_-_Dhaka_-_13th_Summit_12-

13_Nov_2005.pdf (accessed 20 June 2016).

Ghani, E 2010. The Service Revolution in South Asia. Oxford University Press, New Delhi.

Government of India 2017. Export Inspection Council, Government of India. Agreement on South Asia $\quad$ Free Trade Area (SAFTA). http://www.eicindia.gov.in/KnowledgeRepository/Certification/SAFTA.aspx\#mainconte nt(accessed 5 March 2018). 
IBEF 2017. Services Sector in India. Indian Brand Equity Foundation. https://www.ibef.org/industry/services.aspx(accessed 5 March 2018).

International Trade $\quad$ Centre $\quad$ (ITC)

2018. Trade Statistics for International Business Development http://www.trademap.org/Country_SelService_TS.aspx?nvpm=1|||||||S00|1|3|1|2|2|1|2|1 |(accessed15 January 2016, 30 March 2017, 20 June 2018).

Kaur, S. \& Nanda, P. 2010. India's Export Potential to other SAARC countries: A gravity model analysis. Journal of Global Economy, 6(3). pp.167-184.

Kaur, S. 2011. Determinants of Export Services of USA with its Asian partners: A panel data analysis. Eurasian Journal of Business and Economics, 4(8), pp. 101-117.

Kelegama, S.2015.SAARC Agreement on Trade in Services: Tardy Progress. The Daily Star. http://www.thedailystar.net/saarc-agreement-on-trade-in-services- tardy-progress51332(accessed 20 June 2016).

Kelegama, S .2014. SAARC Agreement on Trade in Services: Tardy progress. The Daily Star. http://www.thedailystar.net/saarc-agreement-on-trade-in- $\quad$ services-tardyprogress-51332(accessed 20 June 2016).

Krakoff, C. (2003, November). SADC: Key Potential Export Markets and the Market Access Barriers Facing Exporters. In Southern Africa Trade Regional Network Symposium, Maputo, Mozambique.

Lagarde, C. 2016. Asia's Advancing Role in the Global Economy, By Christine Lagarde, Managing Director, International Monetary Fund. https://www.imf.org/en/News/Articles/2015/09/28/04/53/sp031216(accessed 10 March 2017).

Macleod, A. 2017. Post-Brexit, Britain could become Europe's trade door to the world and it's all down to China. The Independent. http://www.independent.co.uk/voices/brexitbritain-asia-pacific-ttp-rcep- commonwealth-trading-a7610966.html (accessed 20 May 2018).

Mattoo, A. (2000). Developing countries in the new round of GATS negotiations: towards a pro-active role. World Economy, 23(4), 471-489.

Mukherjee, A. 2013. The Service Sector in India. Asian Development Bank Economics. Working Paper Series 352. pp. 1-18.

Mukherjee, A., \& Goyal, T. M. 2013. Examining Mode 4 Commitments in India and the EU's Agreements: Implication for the India-EU BTIA. Indian Institute of Management Bangalore. Working Paper No. 396. pp. 1-29.

Nadkarni, V. 2014. India and SAARC. Department of Political Science, University of San Diego. http://web.isanet.org/Web/Conferences/FLACSOISA\%20BuenosAires\%20 2014/Archive/1226fcdb-083a-4d19-97bb- 6f95edd84685.pdf(accessed 10 March 2017).

Nyatanga, P. 2017. Zimbabwe's Trade Performance Under Alternative Trade Policy Regimes: An Error-correction Model Approach. Foreign Trade Review,52(2). pp 90-105. 
OECD 2017. OECD Services Trade Restrictiveness Index (STRI): India. https://www.oecd.org/india/STRI_IND.pdf(accessed 20 June 2018).

Pandey, P. R., Adhikari, R., \& Waglé, S. 2014. Nepal's Accession to the World Trade Organization: Case Study of Issues Relevant to Least Developed Countries. United Nations, Department of Economic \& Social Affairs. pp 1-33.

Pandey, P.R 2014. Deeper Integration with Human Face, Agenda for SAARC. Trade Insight. South Asia Watch on Trade Economics and Environment 10(2). pp 18-22.

Raihan, S. 2013. Services Trade Liberalization in South Asia. Department of Economics, University of Dhaka, Bangladesh and South Asian Network on Economic Modeling (SANEM). pp1-20.

Razzaque, M. A., \& Basnett, Y. 2014. Regional Integration in South Asia: Trends, Challenges and Prospects. Commonwealth Secretariat.

Repeckaite, D. 2017. Why South Asia makes a good match for Britain after Brexit.

Financial Times. January, 29. https://www.ft.com/content/999adb1c-e3b7- 11e6-84059e5580d6e5fb (accessed 20 May 2018).

SAARC (2010). SAARC Agreement on Trade in Services (SATIS). http://commerce.nic.in/trade/SAARC\%20Agreement\%20on\%20Trade\%20in\%20Service s\%20SATS.pdf (accessed 5 May 2016).

SAARC, (2017). Economic Trade and Finance, Economic and Financial Cooperation. http://saarc- sec.org/areas_of_cooperation/area_detail/economic-trade-andfinance/click-for-details_7(accessed 10 March 2018).

Sandeep, K. (2015). Migration and Bilateral Trade Flows: Evidence from India and OECD Countries. Applied Econometrics and International Development, 15(2), pp179-196.

State Bank of Pakistan (2004). Macroeconomic and Financial Sector Comparison with SAARC \& ASEAN countries.<http://www.sbp.org.pk/publications/FSA2004/Chapter10.pdf.>(accessed 20 November 2016).

Shinohara, N. 2012. Asia's Economic Integration: A Driver of Global Growth in the 21st Century. https://www.imf.org/en/News/Articles/2015/09/28/04/53/sp112012

The Himalayan Times 2017. 10 $0^{\text {th }}$ South Asia Economic Summit Concludes. November.https://thehimalayantimes.com/business/10th-south-asia-economicsummit-concludes/ (accessed 20 June 2018).

The Financial Express (2005).What is SAFTA, What are its benefits? http://www.financialexpress.com/archive/what-is-safta-what-are-itsbenefits/159142/(accessed 20 June 2016).

United Nations Conference on Trade and Development. 2018. International Trade in Services < http://unctad.org/en/conferences/gsf/2013/Pages/Data-on-services.aspx> (accessed January 2016, March 2017 and 20 June 2018).

Wolfmayr, Y. 2008. Trade Barriers in Services and Competitive Strengths in the Austrian Service Sector-An Analysis at the Detailed Sector Level. 
http://www.fiw.ac.at/fileadmin/Documents/Publikationen/fiwstudie7.pdf(accessed January 2017).

World Bank. 2015. Export Competitiveness, Export Trends and Trade Structure Indices: Retrieved from Export trends and Trade Structure Indices-World Bank.

World Bank. 2015. World Development Indicators http://databank.worldbank.org/data/home.aspx(accessed 10 June 2017).

World Bank. 2017 Services Trade Restriction Index. Retrieved from: http://iresearch.worldbank.org/servicetrade/(accessed 4 May 2018).

World Bank. 2017. The Potential of Intra-Regional Trade for South Asia. http://www.worldbank.org/en/news/infographic/2016/05/24/the-potential-of-intraregional-trade-for-south-asia(accessed 10 May 2018).

World Trade Organization. 2005. Ministerial Declaration, Service Negotiations. https://www.wto.org/english/thewto_e/minist_e/min05_e/final_text_e.htm (accessed 4 December 2017).

World Trade Organization. 2015. Services, The General Agreement on Trade in Services (GATS): Objectives, Coverage and Disciplines.

https://www.wto.org/error/error_404.htm (accessed 8 October 2017).

World Trade Organization. 2015. World Trade Organization's Statistical Data Sets-Metadata.

Retrieved from http://stat.wto.org/StatisticalProgram/WSDBStatProgramTechNotes(accessed 05 May 2018).

World Trade Organization. 2017. Services negotiations, Timeline. https://www.wto.org/english/tratop_e/serv_e/s_negs_e.htm(accessed 15 April 2018).

World Trade Organization. 2017. Service trade, The Service Negotiations, Regional Trade Agreements. http://i-tip.wto.org/services/SearchResultRTA.aspx(accessed 20 May 2018).

Yusuf, D., (2006). Trade Potential between South Africa and Angola. Retrieved May, 02, 2018 from:<http://s3.amazonaws.com/zanran_storage/www.nda.agric.za/ContentPages/4 42727952.pdf $>$. 


\begin{tabular}{|c|c|c|c|c|c|c|c|c|}
\hline \multicolumn{9}{|c|}{ Appendix 1} \\
\hline \multicolumn{9}{|c|}{ SAARC Country Wise Average Sum Trade Potential(2000-2016) } \\
\hline \multirow[t]{14}{*}{ Afghanistan } & Services & $\begin{array}{c}\text { AFG } \\
\text { Exports to } \\
\text { SAARC } \\
\end{array}$ & $\begin{array}{c}\text { AFG } \\
\text { Exports to } \\
\text { World } \\
\end{array}$ & $\begin{array}{l}\text { Share of SAARC } \\
\text { in AFG Exports }\end{array}$ & $\begin{array}{l}\text { SAARC Imports } \\
\text { from World }\end{array}$ & $\begin{array}{c}\text { Share of AFG } \\
\text { in SAARC } \\
\text { Import }\end{array}$ & $\begin{array}{c}\text { Indicative } \\
\text { Potential Trade }\end{array}$ & $\begin{array}{l}\text { Underdeveloped } \\
\text { Trade Potential }\end{array}$ \\
\hline & CATEGORY & $\mathbf{A}$ & B & $\mathrm{C}=\mathrm{A} / \mathrm{B} * \mathbf{1 0 0}$ & D & $\mathrm{E}=\mathrm{A} / \mathrm{D} * 100$ & $\mathbf{F}=\min (\mathbf{B}, \mathbf{D})-\mathbf{A}$ & $\mathbf{G}=\mathbf{F}-\mathbf{A}$ \\
\hline & Total services & 17898.92 & 1759970 & 1.02 & 1613360 & 1.11 & 1595461.08 & 1577562.16 \\
\hline & Transport & 2369.23 & 217700 & 1.09 & 728060 & 0.33 & 215330.77 & 212961.53 \\
\hline & Travel & 817.66 & 251490 & 0.33 & 193480 & 0.42 & 192662.34 & 191844.68 \\
\hline & Communications & 1369.87 & 41090 & 3.33 & 11067740 & 0.01 & 39720.13 & 38350.26 \\
\hline & Construction & 5557.69 & 20730 & 26.8 & 17392781 & 0.03 & 15172.31 & 9614.62 \\
\hline & Insurance & 360.96 & 26930 & 1.34 & 71674315 & 0.00 & 26569.04 & 26208.07 \\
\hline & Financial services & 2153.19 & 60870 & 3.54 & 65001236 & 0.00 & 58716.81 & 56563.61 \\
\hline & $\begin{array}{l}\text { Computer and } \\
\text { information }\end{array}$ & 395.71 & 517240 & 0.08 & 33511815 & 0.00 & 516844.29 & 516448.59 \\
\hline & Royalties and licence fees & -278.95 & 3880 & -7.19 & 38807180 & 0.00 & 4158.95 & 4437.89 \\
\hline & Other business services & 24947.55 & 520750 & 4.79 & 354515497 & 0.01 & 495802.45 & 470854.90 \\
\hline & $\begin{array}{l}\text { Personal, cultural and } \\
\text { recreational services }\end{array}$ & 234.59 & 9090 & 2.58 & 15296591 & 0.00 & 8855.41 & 8620.82 \\
\hline & Government services n.i.e. & 2554.76 & 56710 & 4.50 & 22490 & 11.36 & 19935.24 & 17380.48 \\
\hline \multirow[t]{14}{*}{ Bangladesh } & Services & $\begin{array}{c}\text { BAN } \\
\text { Exports to } \\
\text { SAARC } \\
\end{array}$ & $\begin{array}{c}\text { BAN } \\
\text { Exports to } \\
\text { World } \\
\end{array}$ & $\begin{array}{c}\text { Share of SAARC } \\
\text { in BAN } \\
\text { Exports } \\
\end{array}$ & $\begin{array}{l}\text { SAARC Imports } \\
\text { from World }\end{array}$ & $\begin{array}{c}\text { Share of BAN } \\
\text { in SAARC } \\
\text { Import } \\
\end{array}$ & $\begin{array}{c}\text { Indicative } \\
\text { Potential Trade }\end{array}$ & $\begin{array}{l}\text { Underdeveloped } \\
\text { Trade Potential }\end{array}$ \\
\hline & CATEGORY & $\mathbf{A}$ & B & $\mathrm{C}=\mathrm{A} / \mathbf{B} * 100$ & $\mathbf{D}$ & $\mathrm{E}=\mathrm{A} / \mathrm{D} * 100$ & $F=\min (B, D)-A$ & $\mathbf{G}=\mathbf{F}-\mathbf{A}$ \\
\hline & Total services & 37720.82 & 1759970 & 2.14 & 1613360 & 2.34 & 1575639.18 & 1537918.35 \\
\hline & Transport & 4189.72 & 217700 & 1.92 & 728060 & 0.58 & 213510.28 & 209320.56 \\
\hline & Travel & 1839.81 & 251490 & 0.73 & 193480 & 0.95 & 191640.19 & 189800.39 \\
\hline & Communications & 3337.73 & 41090 & 8.12 & 11067740 & 0.03 & 37752.27 & 34414.54 \\
\hline & Construction & 1510.99 & 20730 & 7.29 & 17392781 & 0.01 & 19219.01 & 17708.02 \\
\hline & Insurance & 242.46 & 26930 & 0.90 & 71674315 & 0.00 & 26687.54 & 26445.08 \\
\hline & Financial services & 1317.38 & 60870 & 2.16 & 65001236 & 0.00 & 59552.62 & 58235.24 \\
\hline & $\begin{array}{l}\text { Computer and } \\
\text { information }\end{array}$ & 1102.87 & 517240 & 0.21 & 33511815 & 0.00 & 516137.13 & 515034.26 \\
\hline & Royalties and licence fees & -274.75 & 3880 & -7.08 & 38807180 & 0.00 & 4154.75 & 4429.51 \\
\hline & Other business services & 25304.27 & 520750 & 4.86 & 354515497 & 0.01 & 495445.73 & 470141.46 \\
\hline & $\begin{array}{l}\text { Personal, cultural and } \\
\text { recreational services }\end{array}$ & 210.02 & 9090 & 2.31 & 15296591 & 0.00 & 8879.98 & 8669.96 \\
\hline & Government services n.i.e. & 17534.31 & 56710 & 30.9 & 22490 & 77.96 & 4955.69 & -12578.62 \\
\hline
\end{tabular}


Contd...

\begin{tabular}{|c|c|c|c|c|c|c|c|c|}
\hline \multirow[t]{14}{*}{ Bhutan } & Services & $\begin{array}{c}\text { BHU } \\
\text { Exports to } \\
\text { SAARC } \\
\end{array}$ & $\begin{array}{c}\text { BHU } \\
\text { Exports to } \\
\text { World } \\
\end{array}$ & $\begin{array}{c}\text { Share of SAARC } \\
\text { in BHU } \\
\text { Exports } \\
\end{array}$ & $\begin{array}{c}\text { SAARC } \\
\text { Imports from } \\
\text { World } \\
\end{array}$ & $\begin{array}{l}\text { Share of BHU in } \\
\text { SAARC Import }\end{array}$ & $\begin{array}{c}\text { Indicative } \\
\text { Potential Trade }\end{array}$ & $\begin{array}{l}\text { Underdeveloped } \\
\text { Trade Potential }\end{array}$ \\
\hline & CATEGORY & $\mathbf{A}$ & B & $\mathrm{C}=\mathrm{A} / \mathrm{B} * 100$ & D & $\mathrm{E}=\mathrm{A} / \mathrm{D} * 100$ & $F=\min (B, D)-A$ & $\mathbf{G}=\mathbf{F}-\mathbf{A}$ \\
\hline & Total services & 5025.89 & 1759970 & 0.29 & 1613360 & 0.31 & 1608334.11 & 1603308.22 \\
\hline & Transport & 1492.23 & 217700 & 0.69 & 728060 & 0.20 & 216207.77 & 214715.55 \\
\hline & Travel & 1035.29 & 251490 & 0.41 & 193480 & 0.54 & 192444.71 & 191409.42 \\
\hline & Communications & 608.04 & 41090 & 1.48 & 11067740 & 0.01 & 40481.96 & 39873.92 \\
\hline & Construction & 1112.77 & 20730 & 5.37 & 17392781 & 0.01 & 19617.23 & 18504.46 \\
\hline & Insurance & 176.66 & 26930 & 0.66 & 71674315 & 0.00 & 26753.34 & 26576.67 \\
\hline & Financial services & 718.11 & 60870 & 1.18 & 65001236 & 0.00 & 60151.89 & 59433.78 \\
\hline & Computer and information & 308.78 & 517240 & 0.06 & 33511815 & 0.00 & 516931.22 & 516622.45 \\
\hline & Royalties and licence fees & -279.97 & 3880 & -7.22 & 38807180 & 0.00 & 4159.97 & 4439.94 \\
\hline & Other business services & 20147.29 & 520750 & 3.87 & 354515497 & 0.01 & 500602.71 & 480455.42 \\
\hline & $\begin{array}{l}\text { Personal, cultural and } \\
\text { recreational services }\end{array}$ & 155.08 & 9090 & 1.71 & 15296591 & 0.00 & 8934.92 & 8779.83 \\
\hline & Government services n.i.e. & 1995.51 & 56710 & 3.52 & 22490 & 8.87 & 20494.49 & 18498.98 \\
\hline \multirow[t]{14}{*}{ India } & Services & $\begin{array}{c}\text { IND } \\
\text { Exports to } \\
\text { SAARC } \\
\end{array}$ & $\begin{array}{c}\text { IND } \\
\text { Exports to } \\
\text { World } \\
\end{array}$ & $\begin{array}{l}\text { Share of SAARC } \\
\text { in IND Exports }\end{array}$ & $\begin{array}{c}\text { SAARC } \\
\text { Imports from } \\
\text { World } \\
\end{array}$ & $\begin{array}{l}\text { Share of IND in } \\
\text { SAARC Import }\end{array}$ & $\begin{array}{c}\text { Indicative } \\
\text { Potential Trade }\end{array}$ & $\begin{array}{l}\text { Underdeveloped } \\
\text { Trade Potential }\end{array}$ \\
\hline & CATEGORY & $\mathbf{A}$ & B & $\mathrm{C}=\mathrm{A} / \mathrm{B} * 100$ & D & $\mathrm{E}=\mathrm{A} / \mathrm{D} * 100$ & $F=\min (B, D)-A$ & $\mathbf{G}=\mathbf{F}-\mathbf{A}$ \\
\hline & Total services & 1556937.91 & 1759970 & 88.5 & 1613360 & 96.50 & 56422.09 & -1500515.82 \\
\hline & Transport & 173395.64 & 217700 & 79.6 & 728060 & 23.82 & 44304.36 & -129091.28 \\
\hline & Travel & 202324.57 & 251490 & 80.5 & 193480 & 104.57 & -8844.57 & -211169.14 \\
\hline & Communications & 29287.33 & 41090 & 71.3 & 11067740 & 0.26 & 11802.67 & -17484.65 \\
\hline & Construction & 14751.75 & 20730 & 71.2 & 17392781 & 0.08 & 5978.25 & -8773.50 \\
\hline & Insurance & 24071.22 & 26930 & 89.4 & 71674315 & 0.03 & 2858.78 & -21212.43 \\
\hline & Financial services & 56606.18 & 60870 & 93.0 & 65001236 & 0.09 & 4263.82 & -52342.35 \\
\hline & Computer and information & 508276.08 & 517240 & 98.3 & 33511815 & 1.52 & 8963.92 & -499312.16 \\
\hline & Royalties and licence fees & 3552.45 & 3880 & 91.6 & 38807180 & 0.01 & 327.55 & -3224.90 \\
\hline & Other business services & 497068.34 & 520750 & 95.5 & 354515497 & 0.14 & 23681.66 & -473386.69 \\
\hline & $\begin{array}{l}\text { Personal, cultural and } \\
\text { recreational services }\end{array}$ & 8871.76 & 9090 & 97.6 & 15296591 & 0.06 & 218.24 & -8653.51 \\
\hline & Government services n.i.e. & 9588.60 & 56710 & 16.9 & 22490 & 42.63 & 12901.40 & 3312.79 \\
\hline
\end{tabular}


Contd....

\begin{tabular}{|c|c|c|c|c|c|c|c|c|}
\hline \multirow[t]{14}{*}{ Maldives } & Services & $\begin{array}{c}\text { MAL } \\
\text { Exports to } \\
\text { SAARC } \\
\end{array}$ & $\begin{array}{c}\text { MAL } \\
\text { Exports to } \\
\text { World } \\
\end{array}$ & $\begin{array}{c}\text { Share of SAARC } \\
\text { in MAL } \\
\text { Exports }\end{array}$ & $\begin{array}{c}\text { SAARC } \\
\text { Imports from } \\
\text { World } \\
\end{array}$ & $\begin{array}{c}\text { Share of MAL } \\
\text { in SAARC } \\
\text { Import } \\
\end{array}$ & $\begin{array}{c}\text { Indicative } \\
\text { Potential Trade }\end{array}$ & $\begin{array}{l}\text { Underdeveloped } \\
\text { Trade Potential }\end{array}$ \\
\hline & CATEGORY & $\mathbf{A}$ & B & $\mathrm{C}=\mathrm{A} / \mathrm{B} * 100$ & D & $\mathrm{E}=\mathrm{A} / \mathbf{D}^{*} \mathbf{1 0 0}$ & $F=\min (B, D)-A$ & $\mathbf{G}=\mathbf{F}-\mathbf{A}$ \\
\hline & Total services & 26670.02 & 1759970 & 1.5 & 1613360 & 1.65 & 1586689.98 & 1560019.95 \\
\hline & Transport & 2408.52 & 217700 & 1.1 & 728060 & 0.33 & 215291.48 & 212882.97 \\
\hline & Travel & 21252.04 & 251490 & 8.5 & 193480 & 10.98 & 172227.96 & 150975.92 \\
\hline & Communications & 1011.42 & 41090 & 2.5 & 11067740 & 0.01 & 40078.58 & 39067.16 \\
\hline & Construction & 1125.71 & 20730 & 5.4 & 17392781 & 0.01 & 19604.29 & 18478.57 \\
\hline & Insurance & 158.32 & 26930 & 0.6 & 71674315 & 0.00 & 26771.68 & 26613.36 \\
\hline & Financial services & 715.27 & 60870 & 1.2 & 65001236 & 0.00 & 60154.73 & 59439.45 \\
\hline & Computer and information & 308.78 & 517240 & 0.1 & 33511815 & 0.00 & 516931.22 & 516622.45 \\
\hline & Royalties and licence fees & -196.72 & 3880 & -5.1 & 38807180 & 0.00 & 4076.72 & 4273.44 \\
\hline & Other business services & 20143.72 & 520750 & 3.9 & 354515497 & 0.01 & 500606.28 & 480462.56 \\
\hline & $\begin{array}{l}\text { Personal, cultural and } \\
\text { recreational services }\end{array}$ & 155.08 & 9090 & 1.7 & 15296591 & 0.00 & 8934.92 & 8779.83 \\
\hline & Government services n.i.e. & 2039.64 & 56710 & 3.6 & 22490 & 9.07 & 20450.36 & 18410.72 \\
\hline \multirow[t]{14}{*}{ Nepal } & Services & $\begin{array}{c}\text { NEP } \\
\text { Exports to } \\
\text { SAARC } \\
\end{array}$ & $\begin{array}{c}\text { NEP } \\
\text { Exports to } \\
\text { World } \\
\end{array}$ & $\begin{array}{l}\text { Share of SAARC } \\
\text { in NEP Exports }\end{array}$ & $\begin{array}{c}\text { SAARC } \\
\text { Imports from } \\
\text { World }\end{array}$ & $\begin{array}{l}\text { Share of NEP in } \\
\text { SAARC Import }\end{array}$ & $\begin{array}{c}\text { Indicative } \\
\text { Potential Trade }\end{array}$ & $\begin{array}{l}\text { Underdeveloped } \\
\text { Trade Potential }\end{array}$ \\
\hline & CATEGORY & $\mathbf{A}$ & B & $\mathrm{C}=\mathrm{A} / \mathrm{B} * 100$ & D & $\mathrm{E}=\mathrm{A} / \mathrm{D} * 100$ & $\mathbf{F}=\min (\mathbf{B}, \mathbf{D})-\mathbf{A}$ & $\mathbf{G}=\mathbf{F}-\mathbf{A}$ \\
\hline & Total services & 16452.37 & 1759970 & 0.9 & 1613360 & 1.02 & 1596907.63 & 1580455.25 \\
\hline & Transport & 1856.60 & 217700 & 0.9 & 728060 & 0.26 & 215843.40 & 213986.80 \\
\hline & Travel & 5372.84 & 251490 & 2.1 & 193480 & 2.78 & 188107.16 & 182734.33 \\
\hline & Communications & 2621.86 & 41090 & 6.4 & 11067740 & 0.02 & 38468.14 & 35846.27 \\
\hline & Construction & 1112.77 & 20730 & 5.4 & 17392781 & 0.01 & 19617.23 & 18504.46 \\
\hline & Insurance & 199.90 & 26930 & 0.7 & 71674315 & 0.00 & 26730.10 & 26530.19 \\
\hline & Financial services & 715.27 & 60870 & 1.2 & 65001236 & 0.00 & 60154.73 & 59439.45 \\
\hline & Computer and information & 308.78 & 517240 & 0.1 & 33511815 & 0.00 & 516931.22 & 516622.45 \\
\hline & Royalties and licence fees & -280.56 & 3880 & -7.2 & 38807180 & 0.00 & 4160.56 & 4441.12 \\
\hline & Other business services & 22292.29 & 520750 & 4.3 & 354515497 & 0.01 & 498457.71 & 476165.42 \\
\hline & $\begin{array}{l}\text { Personal, cultural and } \\
\text { recreational services }\end{array}$ & 155.08 & 9090 & 1.7 & 15296591 & 0.00 & 8934.92 & 8779.83 \\
\hline & Government services n.i.e. & 4698.53 & 56710 & 8.3 & 22490 & 20.89 & 17791.47 & 13092.94 \\
\hline
\end{tabular}


Contd...

\begin{tabular}{|c|c|c|c|c|c|c|c|c|}
\hline \multirow[t]{14}{*}{ Pakistan } & Services & $\begin{array}{l}\text { PAK Exports } \\
\text { to SAARC }\end{array}$ & $\begin{array}{c}\text { PAK } \\
\text { Exports to } \\
\text { World }\end{array}$ & $\begin{array}{c}\text { Share of } \\
\text { SAARC in } \\
\text { PAK Exports }\end{array}$ & $\begin{array}{c}\text { SAARC } \\
\text { Imports from } \\
\text { World } \\
\end{array}$ & $\begin{array}{l}\text { Share of PAK in } \\
\text { SAARC Import }\end{array}$ & $\begin{array}{c}\text { Indicative } \\
\text { Potential Trade }\end{array}$ & $\begin{array}{l}\text { Underdeveloped } \\
\text { Trade Potential }\end{array}$ \\
\hline & CATEGORY & $\mathbf{A}$ & B & $\mathrm{C}=\mathrm{A} / \mathrm{B} * 100$ & D & $\mathrm{E}=\mathrm{A} / \mathrm{D} * 100$ & $\mathbf{F}=\min (\mathbf{B}, \mathbf{D})-\mathbf{A}$ & G=F-A \\
\hline & Total services & 73983.72 & 1759970 & 4.2 & 1613360 & 4.59 & 1539376.28 & 1465392.56 \\
\hline & Transport & 20417.36 & 217700 & 9.4 & 728060 & 2.80 & 197282.64 & 176865.29 \\
\hline & Travel & 4482.20 & 251490 & 1.8 & 193480 & 2.32 & 188997.80 & 184515.61 \\
\hline & Communications & 5076.44 & 41090 & 12.4 & 11067740 & 0.05 & 36013.56 & 30937.12 \\
\hline & Construction & 1552.50 & 20730 & 7.5 & 17392781 & 0.01 & 19177.50 & 17625.00 \\
\hline & Insurance & 932.41 & 26930 & 3.5 & 71674315 & 0.00 & 25997.59 & 25065.17 \\
\hline & Financial services & 1707.07 & 60870 & 2.8 & 65001236 & 0.00 & 59162.93 & 57455.85 \\
\hline & Computer and information & 3491.04 & 517240 & 0.7 & 33511815 & 0.01 & 513748.96 & 510257.92 \\
\hline & Royalties and licence fees & -44.86 & 3880 & -1.2 & 38807180 & 0.00 & 3924.86 & 3969.72 \\
\hline & Other business services & 29097.24 & 520750 & 5.6 & 354515497 & 0.01 & 491652.76 & 462555.52 \\
\hline & $\begin{array}{c}\text { Personal, cultural and } \\
\text { recreational services }\end{array}$ & 185.88 & 9090 & 2.0 & 15296591 & 0.00 & 8904.12 & 8718.23 \\
\hline & Government services n.i.e. & 29619.42 & 56710 & 52.2 & 22490 & 131.70 & -7129.42 & -36748.84 \\
\hline \multirow[t]{14}{*}{ Sri Lanka } & Services & $\begin{array}{l}\text { SRI Exports to } \\
\text { SAARC }\end{array}$ & $\begin{array}{l}\text { SRI Exports } \\
\text { to World }\end{array}$ & $\begin{array}{c}\text { Share of } \\
\text { SAARC in } \\
\text { SRI Exports }\end{array}$ & $\begin{array}{c}\text { SAARC } \\
\text { Imports from } \\
\text { World } \\
\end{array}$ & $\begin{array}{l}\text { Share of SRI in } \\
\text { SAARC Import }\end{array}$ & $\begin{array}{c}\text { Indicative } \\
\text { Potential Trade }\end{array}$ & $\begin{array}{l}\text { Underdeveloped } \\
\text { Trade Potential }\end{array}$ \\
\hline & CATEGORY & $\mathbf{A}$ & B & $\mathrm{C}=\mathrm{A} / \mathrm{B} * 100$ & D & $\mathrm{E}=\mathrm{A} / \mathrm{D} * 100$ & $\mathbf{F}=\min (\mathbf{B}, \mathbf{D})-\mathbf{A}$ & $\mathbf{G}=\mathbf{F}-\mathbf{A}$ \\
\hline & Total services & 52390.22 & 1759970 & 3.0 & 1613360 & 3.25 & 1560969.78 & 1508579.56 \\
\hline & Transport & 20074.50 & 217700 & 9.2 & 728060 & 2.76 & 197625.50 & 177551.00 \\
\hline & Travel & 17187.73 & 251490 & 6.8 & 193480 & 8.88 & 176292.27 & 159104.53 \\
\hline & Communications & 1966.59 & 41090 & 4.8 & 11067740 & 0.02 & 39123.41 & 37156.82 \\
\hline & Construction & 1795.21 & 20730 & 8.7 & 17392781 & 0.01 & 18934.79 & 17139.59 \\
\hline & Insurance & 1825.76 & 26930 & 6.8 & 71674315 & 0.00 & 25104.24 & 23278.48 \\
\hline & Financial services & 1944.43 & 60870 & 3.2 & 65001236 & 0.00 & 58925.57 & 56981.14 \\
\hline & Computer and information & 5209.40 & 517240 & 1.0 & 33511815 & 0.02 & 512030.60 & 506821.19 \\
\hline & Royalties and licence fees & -280.56 & 3880 & -7.2 & 38807180 & 0.00 & 4160.56 & 4441.12 \\
\hline & Other business services & 22755.36 & 520750 & 4.4 & 354515497 & 0.01 & 497994.64 & 475239.29 \\
\hline & $\begin{array}{c}\text { Personal, cultural and } \\
\text { recreational services }\end{array}$ & 208.08 & 9090 & 2.3 & 15296591 & 0.00 & 8881.92 & 8673.83 \\
\hline & Government services n.i.e. & 2357.70 & 56710 & 4.2 & 22490 & 10.48 & 20132.30 & 17774.60 \\
\hline
\end{tabular}




\section{Appendix 2}

\begin{tabular}{|c|c|c|c|c|c|}
\hline \multicolumn{6}{|c|}{ Services } \\
\hline \multirow[t]{24}{*}{ AFG } & \multirow{3}{*}{ Limitations on Market Access } & \multicolumn{3}{|r|}{ Transport } & \multirow{3}{*}{ Unbound, except as indicated in the horizontal section } \\
\hline & & \multicolumn{3}{|r|}{ Unbound, except as indicated in the horizontal section } & \\
\hline & & None & & & \\
\hline & Limitations on National Treatment & None & None & Unbound, except as indicated in the horizontal section & Unbound, except as indicated in the horizontal section \\
\hline & \multicolumn{5}{|c|}{ Travel Services } \\
\hline & Limitations on Market Access & & None & Unbound, except as indicated in the horizontal section & Unbound, except as indicated in the horizontal section \\
\hline & & None & & & \\
\hline & Limitations on National Treatment & & None & Unbound, except as indicated in the horizontal section & Unbound, except as indicated in the horizontal section \\
\hline & & None & & & \\
\hline & \multicolumn{5}{|c|}{ Communications Services } \\
\hline & Limitations on Market Access & & None & Unbound, except as indicated in the horizontal section & Unbound, except as indicated in the horizontal section \\
\hline & & None & & & \\
\hline & Limitations on National Treatment & None & None & Unbound, except as indicated in the horizontal section & Unbound, except as indicated in the horizontal section \\
\hline & \multicolumn{5}{|c|}{ Construction Services } \\
\hline & Limitations on Market Access & None & None & Unbound, except as indicated in the horizontal section & Unbound, except as indicated in the horizontal section \\
\hline & Limitations on National Treatment & & None & Unbound, except as indicated in the horizontal section & Unbound, except as indicated in the horizontal section \\
\hline & & None & & & \\
\hline & \multicolumn{5}{|l|}{ Financial services } \\
\hline & Limitations on Market Access & & None & Unbound, except as indicated in the horizontal section & Unbound, except as indicated in the horizontal section \\
\hline & & None & & & \\
\hline & Limitations on National Treatment & & None & Unbound, except as indicated in the horizontal section & Unbound, except as indicated in the horizontal section \\
\hline & & None & & & \\
\hline & \multicolumn{5}{|l|}{ Other Business Services } \\
\hline & Limitations on Market Access & None & None & Unbound, except as indicated in the horizontal section & Unbound, except as indicated in the horizontal section \\
\hline & Limitations on National Treatment & & None & Unbound, except as indicated in the horizontal section & Unbound, except as indicated in the horizontal section \\
\hline & & None & & & \\
\hline & \multicolumn{5}{|c|}{ Personal, Cultural And Recreational Services } \\
\hline & Limitations on Market Access & None & None & Unbound, except as indicated in the horizontal section & Unbound, except as indicated in the horizontal section \\
\hline
\end{tabular}




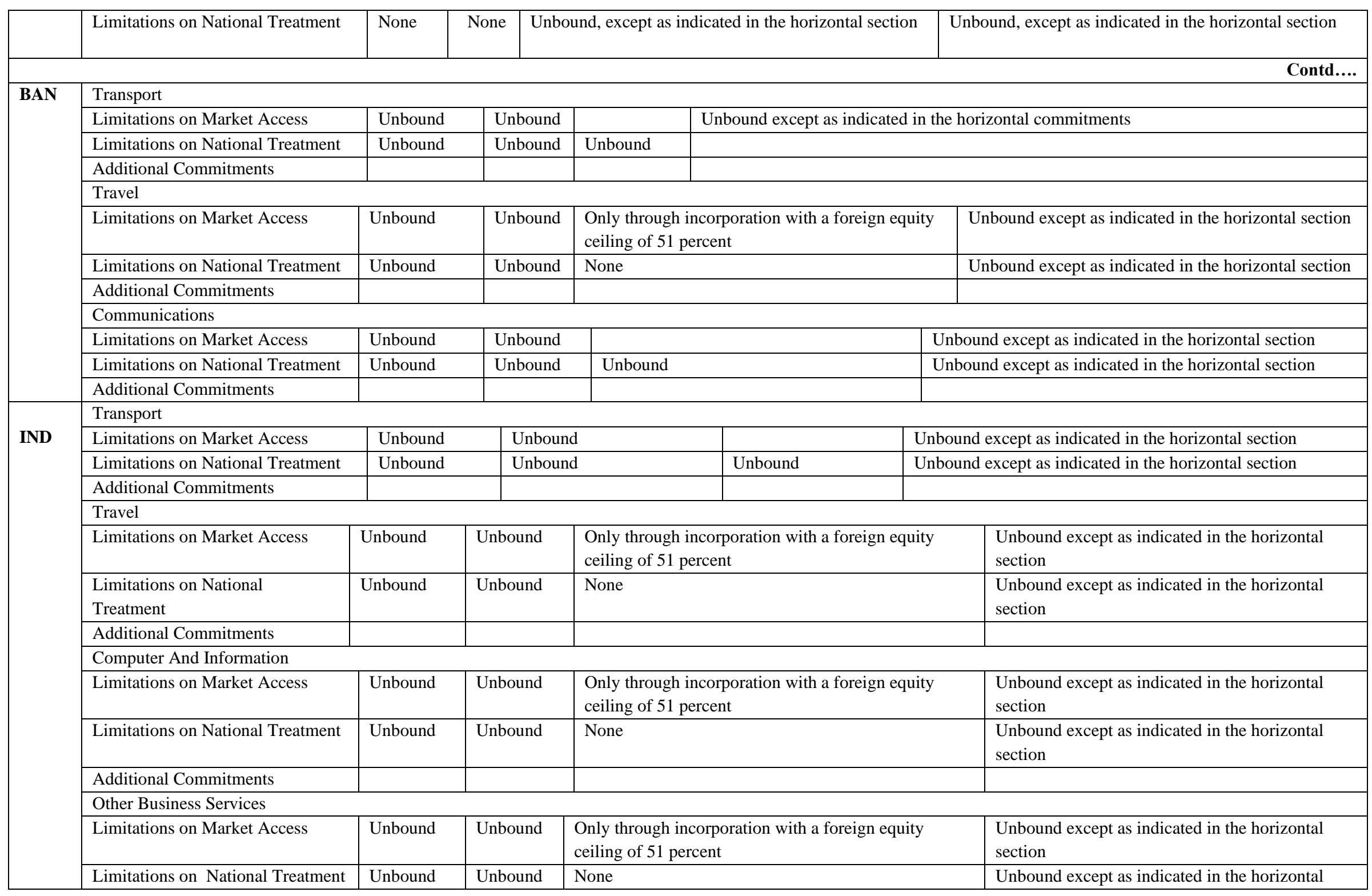




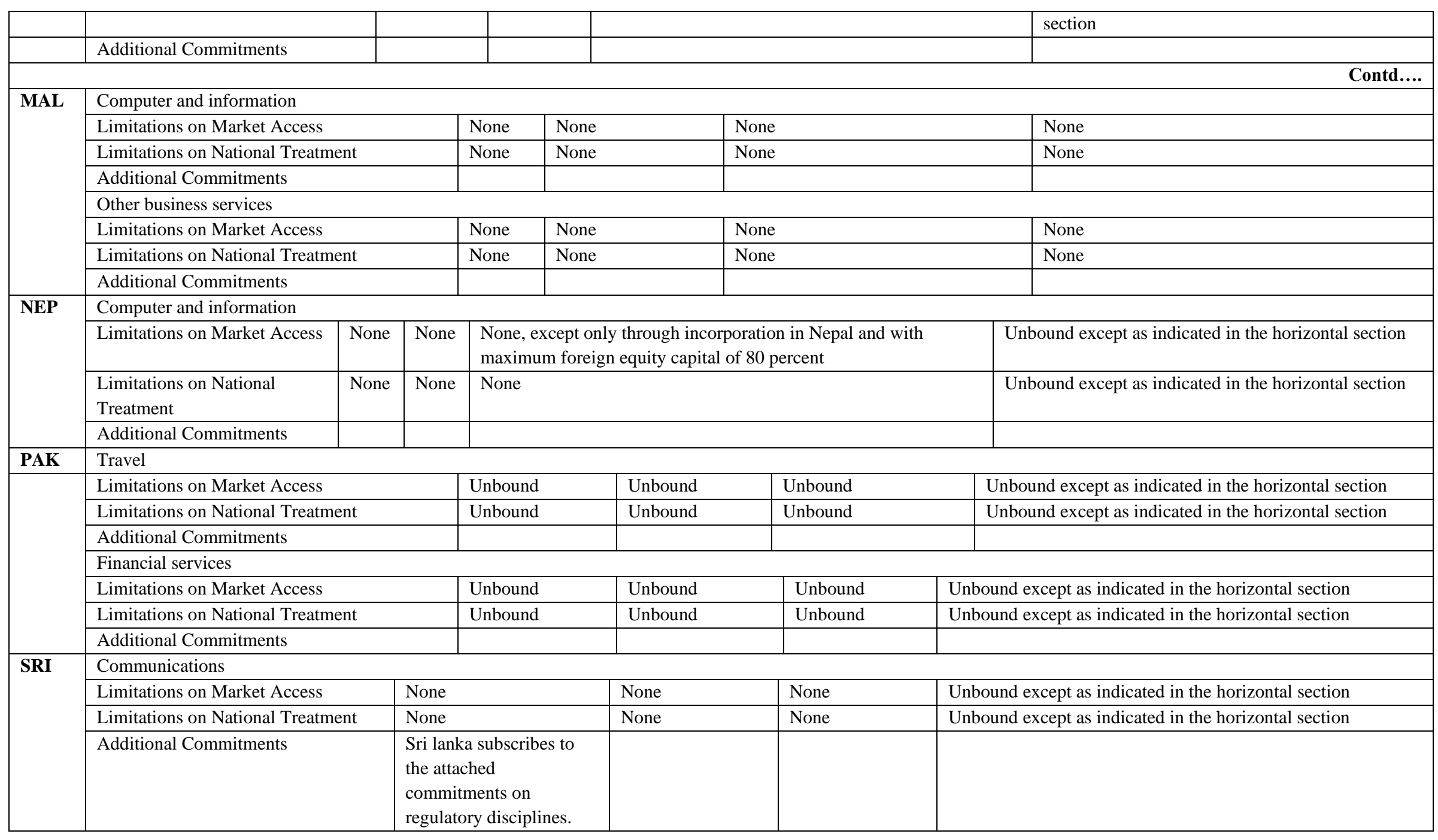


Acknowledgements: We are thankful for the research assistance of Mr. Gulshan Bhat and Mr. Arif Gulzar (Research Scholars, Central University of Punjab, Bathinda) for this article. 